\title{
INSTITUTIONAL ECONOMIC THEORY OF ASSETS PRIVATIZATION AND NATIONALIZATION: BASIC IMPERATIVES
}

\begin{abstract}
Basic provisions, principles and criteria of institutional theory of privatization - nationalization and assets management in economy are introduced. Structural analysis of property, in the aspect of it s two basic elements, public and private property, is carried out and the model of interaction of public and private sectors is introduced. The main attention is focused on the efficiency estimation criteria of the functioning of property and to expediency substantiation of property privatization and nationalization. The optimum principle of property structure in economic system is suggested. Peculiarities of privatization and nationalization in economic systems are analyzed proceeding from substantiation of theoretical criteria of privatization and nationalization in economy.
\end{abstract}

Key words: property, structure, privatization, nationalization, efficiency criteria, optimum principle

\section{Privatization process: possible benefits and costs}

As experience shows, privatization is possible in two basic variants which define all other reasons, consequences and final efficiency of privatization, as well as its scale. The first variant is privatization in capitalist economic system with its history. As a rule, the main objectives of privatization are the necessity to activate private sector functioning, to stimulate competition, to solve the country's budget problems, to react to crisis or stagnation in separate economy sectors with high share of public property, to lower the costs of public sector management, and to reduce inefficiency level in this sector, to solve the problem of structural changes management in the economy in order to raise structural efficiency, to develop separate strategic sectors and to stimulate investment activity. Besides, there are ideological or party reasons which are reduced to preference of privatization before nationalization or to belief that private sector is more effective. Usually, this belief is based on nothing. To prove the superiority

Professor Oleg Sukharev, PhD, Institute of Economics, Russian Academy of Sciences, Moscow, Russia, e-mail: o_sukharev@list.ru. 
on non-comparable kinds of efficiency is practically impossible. Generally, the arguments are given without the exact analysis of all costs and privatization consequences, including remote consequences. Consequently, the interval on which this efficiency/inefficiency is appraised is important at efficiency estimation. The second variant is privatization in the economic system undergoing transformation, for example, from centralized management to capitalist market economy. Here privatization purposes and problems are subordinated to the logic of transformation and actually carry out the function of this transformation in essence. In this case the necessity to create private sector and private proprietor becomes the basic reason of privatization, and it is always added, that the proprietor should be effective. The last concept needs comments as it is not absolutely clear whom to consider efficient and inefficient proprietor. If the agent obtained property at too low cost, will he be an effective proprietor? The fact of purchase at high or low asset price does not automatically mean that a new proprietor is effective or ineffective. There may be any result. And the efficiency principle may be built into the description of the proprietor behavior model. It is possible to offer such principle of efficiency, in particular: the proprietor is effective, if he provides the greatest possible added cost of the asset which he has obtained during privatization not losing the asset, but using it up to its wear-out. Simultaneously, this asset should solve the problem of other assets increment and creations of new assets, that is, capital increment. And the purchase should be paid back in a certain period of time. For the proprietor such purchase of property is a certain investment project (participation in privatization). For the state privatization should also be considered as a project. Hence, „the investment logic“ of such project estimations is quite applicable to privatization as to a certain system of actions, it being useful to carry out efficiency estimation on different assets separately and for privatization as macroeconomic problem in whole ${ }^{1}$ [1-3].

As we see, privatization purposes can be different, and they are determined by the initial condition of economic system in which privatization can be carried out. A different thing is important. Some purposes can be combined and then to speak about the prevalence of a certain purpose calling forth privatization, is inexpedient. Thus, privatization depends on the initial purposes and the state of economic system. The scale and speed of privatization, the price of the assets sold and the total gain which privatization will bring to the budget should be defined by these purposes. At the same time, transformational costs of privatization can appear to be large enough, so that privatization efficiency will be too low on any time interval. There can be inefficient economy structure during privatization, losses of certain assets of a specialization are possible, without

Sukharev O. S. (2013): Privatization, Nationalization and Economic Reform. Finansy i Statistika (Finance and statistics), Moscow; Sukharev O.S. (2013): Theory of economic changes: problems and decisions. KRASAND, Moscow; Sappington D., Stiglitz J. (1987):,,Privatization, Information and Incentives“, Journal of Political Analysis and Management, Vol. 6, № 4, 567-582. 
which it is impossible to imagine functioning of separate economy sectors and activities. These losses should also be considered. That's another matter, that it is impossible to predict the costs at a certain initial moment of privatization planning and realization according to this or that specific plan-form. However, in the capitalist system the agent's adaptation is more flexible and such losses can be essentially less there, than at the solution of transformation problem. That is why, by the way, the researches, concerning former post-Soviet economies and privatization researches in developed or even developing, but capitalist countries are generally non-comparable and their results cannot be interpreted or generalized in the comparative aspect, especially, transferring conclusions to other economies. Each similar research needs to be extra verified, especially, if it is aimed to determine certain laws of privatization or its productivity on a number of countries with non - comparable economies. There cannot be similarity or absolutely identical properties on all parameters of the process progressing in different environment if only it is accidental. If the scale and speed of privatization differ, it is already enough to affect efficiency of the given process.

Privatization and nationalization are aimed at changing the property structures. Certainly, there is a fair question, why it should be changed. The answer is the incentive of the government which is formed due to various reasons. So, the overall purpose of privatization and nationalization is to generate a different property structure. This purpose can be called long-term. Change of the structure property leads to change of investment streams. Besides, ,investment portfolio" of both private trader and the government also changes. When the objective is short-term, the purpose is budget incomes. That is why, both privatization, and nationalization as means of economic policy have serious impact on social institutions, economic structure and the remote prospects of economy development irrespective of their scale. If the state can not manage its assets, it can initiate privatization and resist any nationalization. It is as a additional load on management, which is not necessary. It is a criterion reflection according to which the agent aspires to earn a certain sum of money at the least possible efforts. This criterion is not suitable for the state, but in reality it is applied in decisionmaking on privatization and nationalization. World experience confirms that aggregate time of privatization and the frequency of its use totally surpass the aggregate time of nationalization and even its scale. In other words, privatization tools prevailed. Here there is an interesting remark. It turns out that the state created an asset, augmented it, and then freed itself from this asset, getting a certain income from its sale. The private sector permanently redistributes assets, but other things being equal, the private owner allows further assets concentration. Perhaps, it is due to the fact that the general size of private wealth for developed country is always or usually essentially less than the national riches and assets in the public sector. Privatization can be started because we do not wish to operate excess asset or because it is poorly operated. The last circumstance 
just says that before making the decision on privatization or nationalization it is necessary to raise a question on management efficiency of the state assets. Moreover, the criteria of such management should be demonstrated to electors as the major estimation indicator of the government efficiency.

Apart from estimation of efficient /inefficient proprietor estimation criterion of privatization efficiency and the criterion of what property structure should be considered rational or optimum for the given economic system are necessary. There is a choice between the necessity to increase government efficiency and privatization, so that this management efficiency will not change. But in the course of privatization it can decrease, because the reduction of the management „volume“ can work as a „demotivator" on the officials and create a mental set: as the asset reduced, and we had operated the bigger one, so will we manage with a smaller asset. Such mental set can lower management efficiency in the public sector.

The criterion of privatization expediency, reduced to estimation of „superfluous tax burdens" is not productive. On the one hand, it follows from the Kaldor-Hicks principle about compensating income (indemnification principle), but, on the other hand, the criterion establishing the difference share of compensating income and additional taxes (losses from taxes) to the value of surtaxes, in essence reduced to the support of some agents group well-being in the ideological plan at realization of certain government actions (for example, privatizations). Being a financial criterion, it becomes rather conditional criterion of privatization owing to the unilateralist. In other words, the balance between taxes, incomes and costs is subject to estimation. Comparing the object which created a certain product in the public sector with its possible functioning in the private sector after privatization, the production volume and costs with the correction on the effect of tax burdens are estimated. However, neither asset loss, nor changing its specialty is considered. There are also a number of other restrictions of this criterion, as well as other criteria. In my opinion, the main disadvantage is reduced to estimation of expenses and incomes of the future period without the account of usual institutional effects which in their great number absolutely liquidate evaluation on this or that criterion.

The public sector scale is defined, first of all, by the size of assets or property which this sector possesses and with which it creates a certain product, and renders services. In this case the public sector scale is defined by price value of the created blessings (products and services) in this sector in the general value of the blessings produced in the economy. First of all, this parameter is not defined by budgetary efficiency or the budget expenses ( budget deficit), as it often follows from tautological computations. When for example, the expenses on state sector and the incomes obtained there are written down, depending on the scale that is, the product share of the general product (including services), and the general productivity of economy on blessings creation and incomes and expenses 
efficiency which automatically depend on the scale. In such correlation there is no detail which is extremely important. What is at issue is the volume of funds, assets, property which is used for blessings creation (products and service) and it sets the most important efficiency value, allows getting a certain income and requires the given expenses. If a greater output of goods and services is created with small assets, the efficiency of such public sector is high.

Both processes ( privatization and nationalization) assume formation and realization of useful functions. And curling of separate functions, or loss of some functions, or their quality decrease due to some factors generates the dysfunction of each process separately (privatization and nationalization) and the general resulting process of property management in particular (the dysfunction of share capital and public administration or the public sector).

Privatization, in my opinion, should not be considered as the form of activity of public sector regulation. The problem is that both private and public sectors are interconnected, and the feedback is nonlinear and complex enough. Therefore more likely, it is a tool of change of property portfolio and assets in economy with the following modification of investments structure, functions and profitability ratio according to the sectors and kinds of activity. Besides, kinds of efficiency which can be applied to the estimation of the process are not limited by the listed above which are often used in various researches, either in this form, or in a reduced and/or aggregated form. Moreover, as the efficiency kinds are various in their meaning, the problem of correlation or priority of choice on the kind of efficiency remains unsolved at decision-making. To the enumerated kinds of efficiency I'd rather add, for example, target efficiency which I would not reduce to the definition of relative effect, but connect it with the possibility to achieve the objective having both quantitative and qualitative measurement (according to corresponding introduced indicators), institutional efficiency which is a complex enough indicator as it is necessary to estimate efficiency of arising or introduced rules, and privatization and nationalization process, that is, administrative efficiency which can be measured, in particular, by comparing productivity of privatization and nationalization, or correlation of target and expected aims on each process separately. Functional efficiency, adaptive efficiencies of the system formed (property structure), efficiency on the area of the efforts application, time, costs, and the criteria which reflect internal and external functioning stability of the public and private sectors are also important kinds of efficiency. ${ }^{2}$

Under conditions of a city privatization becomes the tool of property contraction of municipal economy and property expansion of the private proprietor. Thus every minute problems of the city budget can be solved without the possibility to foresee the consequences of scale privatization within the limits of

Efficiency kinds and the ways of their estimation are described in more details in the book: Sukharev O.S. (2009). Efficiency Theory in Economy (2009), Financy I Statistika (Finances and Statistics), Moscow. It is available at www.osukharev.com

Vol. 12, No 1, 2015: 3-30 
municipal economy. Most likely, privatization can be substantiated within the limits of municipal economy when due to privatization transaction a large project on city infrastructure development will be realized, and the asset of city property sale will act as a certain security, meaning that investors will not lose their means invested in this large project. Tentatively speaking, such privatization will be an original security payment while realizing infrastructural project of city development. It should be especially underlined that such privatization cannot have large-scale character. It is subordinated only to the problem of infrastructure development of the city to increase infrastructural efficiency. And it means the general organization efficiency of municipal economy. Besides, privatization can prove its value, if it allows taking steps aimed against deindustrialization, but, on the contrary, on new industrialization of municipal economy. However, it should be mentioned, that in this case, it is necessary to consider and substantiate the possibility of nationalization, that is, liquidation of negative results of previous privatization. These mechanisms do not exist in Russia now. They must be developed at the level of basic federal laws.

\section{Principles and criteria of privatization efficiency}

Let's formulate the fundamental criterion of how the tools of privatization and nationalization influence the property structure in the economy ${ }^{3}$.

Let's introduce income value $(D)$ and expenses value $(Z)$ of privatization $\left(D_{p}\right.$, $\left.\mathrm{Z}_{\mathrm{P}}\right)$ and nationalization $\left(\mathrm{D}_{\mathrm{N}}, \mathrm{Z}_{\mathrm{N}}\right)$ accordingly. Considering the expenses with minus sign, it is possible to write down the basic criterion in the following way:

$$
\mathrm{D}_{\mathrm{P}}+\mathrm{Z}_{\mathrm{P}}+\mathrm{D}_{\mathrm{N}}+\mathrm{Z}_{\mathrm{N}}>0
$$

Income and costs of privatization and nationalization should be considered for the chosen time interval, and the criterion can be carried out for the interval of, say, 4 years, but cannot be carried out for the interval of 1 or 2 years, or vice versa. This criterion can be applied to the asset unit subject to privatization or nationalization. Thus it is unimportant, that nationalized and privatized assets are different assets. By the way, if one tool, for example, privatization, or nationalization is applied, inequalities are transformed accordingly. If there is a criterion default on some time interval, correction of economic policy is necessary, either for the account of privatization of some more kinds of assets (property), or for the account of nationalization. Income and costs should be discounted on a considered time interval for the chosen basis.

Sukharev O. S. (2013): Privatization, Nationalization and Economic Reform. Finansy i Statistika (Finance and statistics), Moscow; Sappington D., Stiglitz J. (1987):,„Privatization, Information and Incentives“, Journal of Political Analysis and Management, Vol. 6, № 4, 567-582. 
Both privatization and nationalization should be considered as inverse tools, and be applied by law. And the law should define the conditions of application of these tools simultaneously on different kinds of assets and for solution of various problems. Anyway, contraposition of privatization and nationalization is absolutely inappropriate neither theoretically, nor practically.

Privatization can be carried out on the following reasons [3].

Firstly, according to ideological considerations when it is necessary to reduce a share of public ownership and the value of the public sector, having created private owner (with its initial absence), or having increased the assets of the available private owners (the subsequent stages of privatization).

The second reason is to provide in payments to the country's budget, especially at its deficit. It is purely fiscal logic of privatization, and such criterion is rather weakly justified as one-time sale of property cannot solve the problem of budget replenishment if private owners are not ready to buy in principle, or they are not ready to buy at the declared price.

Thirdly, efficiency of the asset which is the property of one owner and efficiency of the asset, transferred/sold as the property to another owner can be different kinds of efficiency because proprietors use it differently and with different responsibility. The niches theory asserts that each kind of property has its own „efficiency niche“. Efficiency changes under other conditions. Hence, to assert that efficiency of private property is always higher than public ownership efficiency is all the same as to compare the taste of apple or orange. For one agent apple is tastier, for another one it is orange, and for the third agent both fruit, or one of them causes allergy. The assertion of the government, that the state ownership is ineffective, causes, at least, bewilderment as the given thesis is proved in no way. It turns out, that the owner himself asserts, that he uses the property inefficiently, but he does not confirm this fact with calculations and besides he does nothing to manage this property more effectively. If you own a house and start selling TV, refrigerator, iron and even less used things, you lose them, but you get a certain income from the sale. Simultaneously, you lose the objects which you have managed and narrow the range of your executive activity. The received income can be small and will be spent quickly enough, that is, it can be used to solve current problems, while strategically your possibilities are narrowed due to the fact that the volume of the asset used is less. If the state appoints a manager, the private owner appoints a manager too to dispose of his property and to control it. The probability of management errors at both levels cannot differ greatly. In both cases there are problems of „principal-agent", division of control and management, possession and management. The argument that any proprietor has the right to do whatever he likes with his property within the limits of law in force, can also be applied to the state which is presented by the government. That is, privatization can be carried out in any volume if the proprietor considers so. He can sell the whole asset. But there is an important 
moment. The matter is that the government is a hired manager of this property, and the original owner of the state (public) property is the people of this state. Therefore such decisions should be made by a plebiscite, a referendum and in no other way. In the last resort, at insignificant volume of privatization this action should have scientifically calculated substantiations and expediency reasoning.

Fourthly, privatization can aid the solution of the management problem of "state-private" sector structure. However, how to define the need in the size of public sector or private sector the formation of which also depends on the privatization form: whether it will be distribution of sold assets (property) or their concentration. And, concentration can be carried out on the following phases of property use, not at the first stage of privatization or at the stage next to it, but, for example, in some time interval. Consideration of privatization from the point of view of competition between the state and private sectors looks rather short-sighted, though indirect kinds of competition are always present in the economy. Conditions for state enterprises and private firms are absolutely not equal as well as the problems, purposes and functions are also different. To equate them is problematic and unnecessary. Thus, it is impossible for defense enterprises to have a purpose to get the maximum profit, or to maximize sales volume as the demand for weapons and equipment is limited by the system of challenges and threats, defense requirements and repelling attacks. At creation of such equipment the concept of profit or sales increase, and standard marketing strategy, as well as competition are certain myths, to say nothing about competition with private sector. But competition is present in labor market, at distribution of financial resources of the government etc. There may be competition with external agents for foreign market and technological competition. But as far as the internal problems of national defense are concerned, purchase of foreign samples mean undermining national defense in the future. Such competition is ruled out. It is necessary to speak not only about conditions equality, but about the system of problems and functions which is necessary to carry out with the least resource expenses, that is, in the most effective way. Indirect forms of competition arise even between the state enterprises.

Fifthly, privatization as well as nationalization can be carried out in certain sectors or one sector in the economy. Thus, as the assets are differentiated, the approach to their privatization should be selective. It should consider assets specification. Influencing strongly the property structure and assets profitability, privatization and nationalization are powerful tools of economic policy.

However, it is always necessary to take into consideration, that these reasons are purely financial. They do not consider other losses, costs which arise in conjugated sectors and kinds of activity, changing the assets specialty, etc., and qualitative characteristics of assets. If a subject owns an asset and asserts, that this possession is inefficient, that he uses the asset inefficiently, then the first action should be reduced to showing where and why there is such inefficiency 
and whether there are means for its liquidation. The subject should use every possibility of efficient asset control. Even if the asset is sold at the lowest price, it will bring positive income which is, in any case, higher than the costs necessary to increase the efficiency of asset use because costs are expenses. For this reason this criterion is absolutely not suitable for privatization substantiation. In this case privatization will be necessary at any asset estimation, but it should not equal to zero.

\section{Nationalization: institutional possibilities (price criterion)}

Unlike privatization, nationalization is aimed at consolidation of state ownership and is connected with budget expenses on purchase of private property. From the point of view of the budget, it is first of all, expenses and increase of aggregate demand. However, privatization which is reduced to sale of state ownership, also leads to growth of the budget income. Even if the property is sold at underestimated price, earnings from sale either reduce budgeted deficit, or make up extra incomes which are distributed in the economy by means of budgetary channels. That also acts as a promotion of aggregate demand. Only if, in the case of privatization, the government can influence redistribution of obtained extra income, then at nationalization, the former owner (private proprietor) of nationalized asset, receives financial resource at once, if it is not expropriation.

Nationalization problems differ from the ones of privatization. Moreover, they are opposite in many respects and qualitatively different.

Firstly, the need of nationalization is connected with military operations or natural disaster, for example, anthropogenic accidents.

Secondly, nationalization solves the problem of preservation of some specific asset or kind of activity which can disappear, being in the private sector. It is known, that the private form of competition can easily liquidate separate kinds of activity and even separate sectors. However, in the system of division of labor within the economy in reproduction cycle, these kinds of activity can play a leading role. That is why, preservation of funds and staff in these spheres can become a state problem. Besides, development of fundamental sectors of high technologies demands additional resources and state policy. Nationalization can become part of such policy under certain historical conditions. In particular, nationalization was a powerful factor of industrialization in the USSR in 19201930s. Other examples are also possible.

Thirdly, nationalization is destined to solve the problems of strengthening and development of public sector and its efficiency increase. The same refers to privatization. Such formulation is classical when privatization and nationalization are used to solve certain problems, not understanding and not seeing the ability of privatization and nationalization to promote efficiency increase 
of both private, and public sectors. It refers not only to the efficiency expressed quantitatively by means of estimation of financial and economic results, but also to the efficiency which can be estimated by a set of qualitative indicators or parameters, which will define long-term development prospects of the specified sectors of economic system.

Fourthly, nationalization can be a tool of opposition to crisis phenomena in the economy, regardless of crisis character - cyclic, transitive or mixed. Besides, it can be applied according to ideological reasons, when the parameters of social and economic development worsen; this or that political force can resort to nationalization as central component of economy reformation. Some other political force can, on the contrary, substantiate the necessity of privatization. This dichotomy in economic science arises due to a politic-ideological dichotomy, but actually, both privatization and nationalization can simultaneously be applied in certain scale as assets are differentiated, and both tools can be used regarding them; one of them can be privatized, others can be nationalized. Another matter, that the general vector of either privatization or nationalization will prevail from the point of view of costs and received income. The situation is possible when income from privatization is then entirely used for nationalization of other private assets. In this case it is important to consider the change of costs and to estimate whether the main identity is fulfilled.

Fifthly, the initial point of the state of economy is important for nationalization, as well as for privatization. If the public sector property surpasses the property of the private sector according to identical estimation criterion, then, other things being equal, the probability of privatization is higher, than that of nationalization. Efficiency criteria are sure important, as well as the criterion of property structure optimality. If there is an invert correlation, probability of nationalization is higher with the same reservations. There is one more important aspect. It is the cost of nationalized and privatized asset. The problem is that each asset is individual and unique. Therefore, it is impossible to apply the instrument of supply and demand to heterogeneous privatized or nationalized objects if only to introduce such model: not to consider the asset to be homogeneous according to the cost per unit (the average cost is equal to total cost divided by the number of assets). However, such simplification is so ", lifeless ", that it is not appropriate to admit it. Further, each asset should be checked regarding the benefits and costs of privatization and nationalization. If real cost $\left(\mathrm{P}_{\mathrm{i}}^{*}\right)$ is higher, than the fixed price at sale or purchase of the asset $\left(\mathrm{P}_{\mathrm{i}}\right)$, the asset is undervalued. In this case nationalization brings additional benefits to the government, and privatization brings losses. However, if the price appears to be higher, than the real price the act (transaction) of privatization cannot take place as the private owner will not get the given asset at overvalued price. The same refers to nationalization. However, it is not absolutely fair, as the state can buy out the asset at higher price, than its actual costs, if the state solves certain strategic problem 
which brings new strategic quality. If the current price of the asset is higher, than its real price we have a situation of overvalued asset. In this case nationalization brings additional losses to the government, and privatization provides additional benefits. Divergence of current price of purchase/sale and real cost of the asset results from information asymmetry which accompanies both privatization, and nationalization, whatever scale they have. And the act of purchase and sale is being made, though the price for certain does not coincide and it is a sign to stop the process. It is the divergence of the given price that makes the essence of benefits and losses for one agent and the others (Table). If the price at which the asset is sold/bought also includes the costs of privatization/nationalization on the given time interval, they are included into the fixed price of the asset, but not in the real price, and will affect price criterion, that is, correlation $\mathrm{P}_{\mathrm{i}}^{*} / \mathrm{P}_{\mathrm{i}}$. It is necessary to notice, that the government can get benefits or incur losses from application of these or those tools of economic policy. It is important, whether it is guided only by benefits and costs in decision-making and whether it considers the benefits and costs of other agents, which are included in privatization and nationalization. It is so, because the prerogative to apply tools in any modern economic system belongs to the government, but not to individual private agents (they cannot declare privatization and nationalization and carry it out).

Table 1: Price Criterion of privatization and nationalization

\begin{tabular}{|l|l|l|}
\hline \multicolumn{1}{|c|}{ Price criterion } & \multicolumn{1}{c|}{ Privatization } & \multicolumn{1}{c|}{ Nationalization } \\
\hline $\begin{array}{l}\mathrm{P}_{\mathrm{i}}^{*} / \mathrm{P}_{\mathrm{i}}>1 \text { - undervalued } \\
\text { asset (property) }\end{array}$ & It is not profitable to the government & It is profitable to the government \\
\hline $\begin{array}{l}\mathrm{P}_{\mathrm{i}}^{*} / \mathrm{P}_{\mathrm{i}}<1 \text { - overvalued } \\
\text { asset (property) }\end{array}$ & It is profitable to a private owner & It is not profitable to a private owner \\
\hline $\mathrm{P}_{\mathrm{i}}^{*}=\mathrm{P}_{\mathrm{i}}$ accurately valued & It is profitable to the government & It is not profitable to the government \\
\hline & It is not profitable to a private owner & It is profitable to a private owner \\
\hline & $\begin{array}{l}\text { They are equiprobable and should assume other criteria at carrying out. } \\
\text { (Solution of strategic problems and quality provision of property, markets } \\
\text { and economy structure, including sect oral structure). To all cases of the } \\
\text { Table the criterion „basic identity of privatization-nationalization“ is applied. } \\
\text { Another matter is that „price criterion“ determines the demand for this or } \\
\text { that asset and the act of privatization or nationalization of this asset itself. }\end{array}$ \\
\hline
\end{tabular}

The one who owns the asset and begins the process is better informed about its real value $\left(\mathrm{P}_{\mathrm{i}}{ }^{*}\right)$. In this connection, the government, carrying out privatization is usually more informed about the state of sold assets and their real value than private agents. In case of nationalization, the government can also possess more and better information about the use of certain assets (former private ones) in the solution of nationalization problems and expansion for the account of this public sector. 
From the Table it is clearly seen, that the balance of benefits for a certain correlation of price for each separately considered kind of asset is important. The asset which the state possesses can only be privatized. And the property of private owner can be nationalized. In the latter case the benefit must be rather tangible. Otherwise there is no incentive to sell this asset.

It is interesting to notice, that in the history of economic system development privatization occurred more often than nationalization though on the average it was less large-scale, than nationalization. In scientific economic literature many researches are devoted to privatization problem, but not nationalization, to say nothing that both processes were not considered simultaneously. However, even in these researches there are erroneous conclusions. As these errors affect decisions and conclusions concerning privatization/nationalization, it is necessary to specify the worst ones grouping them into three basic categories.

The first group of errors. They are connected with incorrect interpretation of privatization and nationalization efficiency, or absence of the criteria in the theory, which allow estimating the first and the second process truly. In particular, there has been a cliché for a long time, as if private enterprise is more effective than public enterprise. Such estimations can exist only accurate within the criterion. And there is a difference between criteria, to say nothing that the difference from the point of view of management is obliterated. Private owner often acts as an isolated owner, who is not successful in realizing the function of control, as well as public owner - the official who should also supervise public enterprises. Thus, in both cases control is given to management which has similar behavior motives, but it often has different problems and tools, responsibility in public sector being usually higher, than in private sector. Furthermore, the criminal law is arranged in the way that punishment for infringements against the state are even more severe, than for infringements in the private sector.

Nationalization increases responsibility and should extend the function of control over the obtained property, as well as the management quality which with asset increase, or an idea, should go down, other things being equal. Hence, from the managements point of view the requirement concerning management in public sector should increase faster than the rate of nationalization.

Privatization cannot at all lead to the equivalent growth of responsibility and control. Besides private proprietor acts as the subject of demand in the labor market of administrative services, and cannot affect administrative personnel training directly if he is not simultaneously a proprietor of the university which carries out such training. But the state possesses this resource.

The second group of errors. It is impossible to compare efficiency of state and private enterprises by conditional criteria and simultaneously compare this efficiency with the efficiency of privatization and nationalization. Efficiency of a kind of property and efficiency of enterprises functioning are two different kinds of efficiency. They can be connected, but usually there are many factors 
which do not coincide and define efficiency of different elements of the system differently. If the asset is obtained at undervalued price comparing with its real price, the state obviously loses from privatization. The private owner wins, but his entrepreneurial motive concerning this asset can change. This leads to the change of the mode of asset use and changes its specialty. Therefore to speak about efficiency is senseless. Efficiency can be compared only equivalently: if the asset was used with one purpose and then ceased to be used with this purpose, the fact of such change means, that efficiency is different, it refers to the other asset use and cannot be compared with the efficiency of previous use. It is necessary to compare the kinds of assets of equivalent use (specialization). One more important remark is about the time of privatization and nationalization. If, for example, there is economic crisis, what is it necessary to carry out in larger scale: privatization or privatization? Probably, such problem statement is incorrect in general, as the crisis phenomena strengthen information asymmetry, distort the asset cost and influence unpredictable redistribution of income and costs even in greater degree, making exact estimation and plausible decision impossible.

Considering, that crisis disorganizes economic system and the markets, it is more expedient to carry out nationalization, or just to realize both strategies on different kinds of assets in various sectors of economy with the general vector aimed at strengthening of the vector of state management and support of aggregate demand, and preservation of technological level (supply), which at slow depression will obviously go down due to the losses of information and personnel.

At economic growth or at the tendency of its slowdown, it is possible to use privatization in large scale to support private initiative. Nobody prevents the governments to develop scenarios of use of the given tools jointly in some scale depending on specific institutional conditions of a certain country, economic policy and legislation.

The third group of errors. The researches of privatization carried out usually concern some historical period for which the conclusions are probably fair. But it does not mean, that they are fair for other period and that they can be used on other interval as a guideline to define economic policy or scale of privatization and nationalization. For example, to claim that privatization has not led to significant increase in investments per unit of output, and firms' investment activity has fallen on some sampling of countries for a certain time interval means nothing. It is not clear, what the significant increase means, what increase should be considered significant, why in general it should occur within the limits of applied scheme and privatization scale. Besides, distracting from other more important factors, such as: level of savings, the state of technologies which can define investment possibilities and even investment activity, and agents propensity to investment and interest rates, such resumes mean little in analytical sense. It is not at all the fact, that privatization should change the motives and define the character of investments in the country. Technological production level and not 
privatization as such defines the efficiency of resource processing. It is absolutely incorrect to analyze privatization as an action, without the account of its depth, time, and kind of assets which it covers and without the account of nationalization as the process which can quite synchronously occur. Thus nationalization is as if opposed to privatization, according to its meaning and logic.

\section{Interaction model of public and private sectors}

Let's imagine an economic system having two sectors - public (G) and private $(\mathrm{P})$ ones. All introduced variables are time function. The corresponding designations of parameters will be the specified letters. Then, the value of product and services (blessings is $\mathrm{Y}$, employment - $\mathrm{P}$, transactional costs - $\mathrm{Tr}$, production (transformational) costs - $C_{p}$, expenses of the state budget - $G$, incomes of the state budget $-\mathrm{T}$. The value of property $\mathrm{Q}$ can be expressed as follows:

$$
\begin{aligned}
& \mathrm{Y}=\mathrm{Y}_{\mathrm{G}}+\mathrm{Y}_{\mathrm{P}} \\
& \mathrm{P}=\mathrm{P}_{\mathrm{G}}+\mathrm{P}_{\mathrm{P}} \\
& \mathrm{Tr}=\mathrm{Tr}_{\mathrm{G}}+\mathrm{Tr}_{\mathrm{P}} \\
& \mathrm{C}_{\mathrm{P}}=\mathrm{C}_{\mathrm{PG}}+\mathrm{C}_{\mathrm{PP}} \\
& \mathrm{G}=\mathrm{G}_{\mathrm{G}}+\mathrm{G}_{\mathrm{P}} \\
& \mathrm{T}=\mathrm{T}_{\mathrm{G}}+\mathrm{T}_{\mathrm{P}} \\
& \mathrm{Q}=\mathrm{Q}_{\mathrm{G}}+\mathrm{Q}_{\mathrm{P}}
\end{aligned}
$$

The value of product, employment, costs, expenses and incomes of the budget, property in state and private sector of the economy are shown by symbols $\mathrm{G}$ and $\mathrm{P}$ accordingly.

Then we will introduce a number of important correlations. The scale of public and private sectors on product share in the total product of economic system is $\mathrm{m} 1=\mathrm{Y}_{\mathrm{G}} / \mathrm{Y}, \mathrm{m} 2=\mathrm{Y}_{\mathrm{P}} / \mathrm{Y}, \mathrm{m} 1 / \mathrm{m} 2=\mu$. Let's specify productivity of the sectors (y), including productivity of public and private sectors on the property (the product obtained from a unit of property, $y 1=\mathrm{Y}_{\mathrm{G}} / \mathrm{Q}_{\mathrm{G}}, \mathrm{y} 2=\mathrm{Y}_{\mathrm{P}} / \mathrm{Q}_{\mathrm{P}}, \varphi=\mathrm{y} 2 / \mathrm{y} 1$ ), the scale of expenses and incomes of each sector on product $\left(g_{G}, t_{G}, g_{p}, t_{p}\right)$ to the total value of budget expenses and incomes $\left(\mathrm{r}_{\mathrm{G}}, \mathrm{r}_{\mathrm{P}}, \chi_{\mathrm{G}}, \chi_{\mathrm{P}}\right)$, and a share of public expenses and incomes in product $\mathrm{Y}(\gamma=\mathrm{G} / \mathrm{Y}, \Psi=\mathrm{T} / \mathrm{Y})$.

We will write down the remaining correlations as follows:

$$
\begin{aligned}
& \mathrm{g}_{\mathrm{G}}=\mathrm{G}_{\mathrm{G}} / \mathrm{Y}_{\mathrm{G}} \\
& \mathrm{g}_{\mathrm{P}}=\mathrm{G}_{\mathrm{P}} / \mathrm{Y}_{\mathrm{P}} \\
& \mathrm{t}_{\mathrm{G}}=\mathrm{T}_{\mathrm{G}} / \mathrm{Y}_{\mathrm{G}} \\
& \mathrm{t}_{\mathrm{P}}=\mathrm{T}_{\mathrm{P}} / \mathrm{Y}_{\mathrm{P}} \\
& \mathrm{r}_{\mathrm{G}}=\mathrm{G}_{\mathrm{G}} / \mathrm{G} \\
& \mathrm{r}_{\mathrm{P}}=\mathrm{G}_{\mathrm{P}} / \mathrm{G} \\
& \chi_{\mathrm{G}_{\mathrm{G}}}=\mathrm{T}_{\mathrm{G}} / \mathrm{T} \\
& \chi_{\mathrm{P}}=\mathrm{T}_{\mathrm{P}} / \mathrm{T}
\end{aligned}
$$


From the point of view of studying property structure, it is important to estimate the scale of public sector not through the share of created product (goods and services), but through the structure change of public and private property to make useful conclusions for description of privatization and nationalization.

Value $m=Q_{G} / Q_{P}$ can be accepted as a structural indicator of public sector scale, representing the ratio parameter of value (in cost expression for current period) of public and private property in economic system.

Using the parameters of sectors productivity on the asset (property) introduced above, yl and y2 accordingly, we will write down:

$\mathrm{y} 1=\mathrm{Y}_{\mathrm{G}} /\left(\mathrm{m} \mathrm{Q}_{\mathrm{P}}\right)$

$\mathrm{y} 2=\mathrm{Y}_{\mathrm{p}} / \mathrm{Q}_{\mathrm{p}}$

Whence it is not difficult to get:

$m=\frac{y 2}{y 1} \frac{m 1}{m 2} \quad ; m=\mu \phi$

Or the following record is possible:

$$
m(t)=\frac{y 2(t)}{y 1(t)} \frac{m 1(t)}{1-m 1(t)}=\frac{y 2(t)}{y 1(t)} \frac{1}{\frac{1}{m 1(t)}-1}=k\left(m 1(t) \frac{y 2(t)}{y 1(t)},\right.
$$

In other words, public sector scale on property value is proportional to the inverse ratio of its productivity to the productivity of private sector where proportionality coefficient is the relation of the scale of public and private sectors on product, or it is a function of scale of public sector on product.

In the simple formulation the public sector scale is a product of relative productivity coefficient and coefficient of sector scale on product, that is, $m(t)=\mu(t) \varphi(t)$.

Having established the relationship of public sector scale on property and product, it is important now to define public sector scale on product, that is, value $\mathrm{ml}(\mathrm{t})$. For this purpose we will write down introduced above correlations

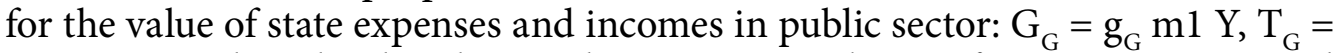
$\mathrm{t}_{\mathrm{G}} \mathrm{ml} \mathrm{Y}$. On the other hand, considering our correlations for state expenses and incomes in public sector, it is possible to write down:

$$
\begin{aligned}
& \mathrm{G}_{\mathrm{G}}=\mathrm{r}_{\mathrm{G}} \mathrm{G}=\mathrm{r}_{\mathrm{G}} \gamma \mathrm{Y}, \\
& \mathrm{T}_{\mathrm{G}}=\chi_{\mathrm{G}} \mathrm{T}=\chi_{\mathrm{G}} \Psi \mathrm{Y}
\end{aligned}
$$

Having equated the received expressions on the state expenses and incomes in public sector accordingly, we will receive:

$\mathrm{r}_{\mathrm{G}} \gamma \mathrm{Y}=\mathrm{g}_{\mathrm{G}} \mathrm{m} 1 \mathrm{Y}$,

$\chi_{\mathrm{G}} \Psi \mathrm{Y}=\mathrm{t}_{\mathrm{G}} \mathrm{ml} \mathrm{Y}$

Let's express a share of expenses and incomes in GDP from the specified equalities: 
$\gamma=\mathrm{g}_{\mathrm{G}} \mathrm{m} 1 / \mathrm{r}_{\mathrm{G}}$
$\Psi=\mathrm{t}_{\mathrm{G}} \mathrm{m} 1 / \chi_{\mathrm{G}}$

Having written down budget deficit $B=G-T$ as $B / Y=G / Y-T / Y$, we receive, that $b=\gamma-\Psi$, where $b=B / Y$. Having substituted the expression for $\gamma$ and $\Psi$, and having done algebraic manipulations, we will finally receive the expression for $\mathrm{ml}(\mathrm{t})$ :

$$
m 1(t)=\frac{\gamma-\psi}{\frac{g_{G}}{r_{G}}-\frac{t_{G}}{\chi_{G}}}
$$

Then the scale of public sector $\mathrm{m}(\mathrm{t})$ will be defined by the expression:

$$
m(t)=\frac{\varphi(t \gamma \gamma(t)-\psi(t)}{\frac{g_{G}(t)}{r_{G}(t)}-\frac{t_{G}(t)}{\chi_{G}(t)}-(\gamma(t)-\psi(t)}
$$

If we designate, $b_{G}(t)=\frac{g(t)}{r_{G}(t)}-\frac{t_{G}(t)}{\chi_{G}(t)}=\frac{G-T}{Y_{G}}$ that is, $\mathrm{b}_{\mathrm{G}}$ - budget deficit per product unit in public sector, then

$$
m(t)=\frac{\varphi(t) b(t)}{b_{G}(t)-b(t)}
$$

Taking a derivative $\mathrm{dm}(\mathrm{t}) / \mathrm{dt}=0$, having carried out all necessary transformations, we will receive:

$$
\left.\frac{d b}{d t}=\frac{b}{b G} \frac{d b_{G}}{d t}-\frac{b\left(b_{G}-b\right)}{b_{G} \varphi} \frac{d \varphi}{d t} \text { Or } \frac{1}{b} \frac{d b}{d t}=\frac{1}{b_{G}} \frac{d b_{G}}{d t}-\frac{\left(b_{G}-b\right)}{b_{G} \varphi} \frac{d \varphi}{d t}{ }^{*}\right)
$$

Thereby, change of budget deficit is equal to change of the deficit per product unit in public sector minus product of speed of relative productivity change of private and public property (product value, created by the kinds of property in the given sector per unit of this property) on coefficient $k=\left(b_{G}-b\right) /\left(b_{G} \varphi\right)$.

This correlation is carried out for extreme of function $\mathrm{m}(\mathrm{t})$ of public sector scale. And if $\mathrm{dm}(\mathrm{t}) / \mathrm{dt}>0$ at $\mathrm{t}<\mathrm{t} 0, \mathrm{dm}(\mathrm{t}) / \mathrm{dt}<0$, at $\mathrm{t}>\mathrm{t} 0$, we have maximum $\mathrm{m}$ $(\mathrm{t})$, the greatest scale of public sector on public property value, and expression $\left.{ }^{*}\right)$ means change of budget deficit corresponding to the maximum point of the public sector scale. Provided that $\mathrm{dm}(\mathrm{t}) / \mathrm{dt}<0$ at $\mathrm{t}<\mathrm{t} 0, \mathrm{dm}(\mathrm{t}) / \mathrm{dt}>0$, at $\mathrm{t}>\mathrm{t} 0$, and realization of $\left(^{*}\right)$, we have minimum of value of public sector on the property value and the corresponding change of budget deficit.

When $m(t)$ grows, we have obvious prevalence of nationalization, or loss of private property (for example, as a result of military actions). If $\mathrm{m}(\mathrm{t})$ is reduced, either there is privatization in the country, or the property is bought by the private sector abroad. 
It is important to notice, that a point of John Sculley is not defined in connection with the product value created in public sector or the rate of its change and property value or its change (rate of share change of expenses in GDP) and growth rate of GDP itself. In this case it is impossible to perceive the value of public sector as the optimum one, as absolutely various assets structure can give various variants of growth rate of the share of public expenses which cannot depend directly on these assets properties. The growth rate is increased proceeding from a certain political necessity. There is no objectivity of these correlations. Moreover, each parameter on which the scale of public sector is set (property value, employment level, product value in the total volume of the corresponding value for national economy, and the value of public expenses in gross product), will give its point of optimum value for the given rate of economic growth. However, if the economy in the current state is to the left of this point, nationalization is more necessary, than privatization, if to be guided only by such criterion. If the economy is to the right of the given point, privatization is more necessary that is, reduction of the scale of public sector. If each criterion has its own point, there is a question: how to establish the general optimum for the scale of public sector. It is supposedly; in this case, to search connection of the specified four parameters defining the borders of public sector, that is, connection between created product in public sector, employment ${ }^{4}$, property value and scale of public expenses in country's GDP. It is necessary to obtain the rate of change of the specified values for the same economic growth rate of the whole economic system.

Let's introduce the following correlations:

$\mathrm{m}(\mathrm{t})=\mathrm{Q}_{\mathrm{G}} / \mathrm{Q}_{\mathrm{P}}$ (public sector scale on property value)

$\mathrm{Z}=\mathrm{Y} / \mathrm{Q}=\mathrm{Y} /\left(\mathrm{Q}_{\mathrm{G}}+\mathrm{Q}_{\mathrm{P}}\right)$ - total productivity of available property (assets) in the economy

$\mathrm{y}=\mathrm{Y} / \mathrm{P}$ (labor productivity in the economy, $\mathrm{P}$ - number of employed)

$\mathrm{i} 1=\mathrm{Q}_{\mathrm{G}} / \mathrm{P}$ - the scale of public sector on property value per one employed in the economy

$\mathrm{i} 2=\mathrm{Q}_{\mathrm{P}} / \mathrm{P}$ - the scale of private sector on private property value per one employed in the economy.

Then it is possible to write down, that $\mathrm{Y}=\mathrm{y} \mathrm{P}$, on the other hand $\mathrm{Y}=\mathrm{Z}$ $\left(\mathrm{Q}_{\mathrm{G}}+\mathrm{Q}_{\mathrm{P}}\right)$ or we received, that $\mathrm{y}=\mathrm{Z}\left(\mathrm{Q}_{\mathrm{G}} / \mathrm{P}+\mathrm{Q}_{\mathrm{P}} / \mathrm{P}\right)=\mathrm{Z}(\mathrm{i} 1+\mathrm{i} 2)$. Considering the expressions for $\mathrm{m}(\mathrm{t}), \mathrm{i} 1, \mathrm{i} 2$, it is easy to notice, that $\mathrm{m}(\mathrm{t})=\mathrm{i} 1 / \mathrm{i} 2$ or $\mathrm{m}(\mathrm{t})=\mathrm{i} 1 \mathrm{Z} /$ $(\mathrm{y}-\mathrm{Z} \mathrm{i} 1)$. Taking a derivative $\mathrm{dm}(\mathrm{t}) / \mathrm{dt}$, having done necessary algebraic manipulations, we will receive:

$$
\begin{aligned}
& \frac{1}{y} \frac{d y}{d t}=\frac{1}{i 1} \frac{d i 1}{d t}+\frac{1}{Z} \frac{d Z}{d t} \\
& \frac{d i 1}{d t}=i 1\left[\frac{1}{y} \frac{d y}{d t}-\frac{1}{Z} \frac{d Z}{d t}\right]
\end{aligned}
$$

By the way, by analogy it is possible to get the value of public sector $\mathrm{m}(\mathrm{t})$, but in connection with the change of the number of employed in public sector. 
The given correlation received for points of extremism of function $\mathrm{m}(\mathrm{t})$ of the scale of public sector means that in these points the scale change of public sector il is proportional to the scale itself, where the proportionality coefficient is the difference of relative changes of development and productivity of assets (property) in economy. In other words, relative change of the size of the state sector il is the difference of relative changes of production and productivity of assets in economy for the points of extremism, that is, where $\mathrm{dm}(\mathrm{t}) / \mathrm{dt}>0, \mathrm{t}<\mathrm{t} 0$ and $\mathrm{dm}(\mathrm{t}) / \mathrm{dt}<0, \mathrm{t}>\mathrm{t} 0$ (maximum point), or $\mathrm{dm}(\mathrm{t}) / \mathrm{dt}<0, \mathrm{t}<\mathrm{t} 0$ and $\mathrm{dm}(\mathrm{t}) / \mathrm{dt}>$ $0, \mathrm{t}>\mathrm{t} 0$ (minimum point).

Having substituted il $=\mathrm{m}(\mathrm{t})$ i2 we will receive the expression for the scale of public sector $\mathrm{m}(\mathrm{t})$ for extremum points of function $\mathrm{m}(\mathrm{t})$, when $\mathrm{dm}(\mathrm{t}) / \mathrm{dt}>0, \mathrm{t}$ $<\mathrm{t} 0$ and $\mathrm{dm}(\mathrm{t}) / \mathrm{dt}<0, \mathrm{t}>\mathrm{t} 0$ (maximum point), or $\mathrm{dm}(\mathrm{t}) / \mathrm{dt}<0, \mathrm{t}<\mathrm{t} 0$ and $\mathrm{dm}(\mathrm{t}) /$ $\mathrm{dt}>0, \mathrm{t}>\mathrm{t} 0$ (minimum point):

$$
\frac{1}{m} \frac{d m}{d t}=\frac{1}{y} \frac{d y}{d t}-\frac{1}{i 2} \frac{d i 2}{d t}-\frac{1}{Z} \frac{d Z}{d t}
$$

Thus, in the points of extremum (for the greatest and the least scale of public sector) the change of scale of this sector is equal to the change of production in economic system minus the change of the scale of private sector (on property) and changes of productivity of all the property (assets) in the economy (value Z).

When there is the maximum point, or the scale of public sector is the closest to this point, the probability of privatization is the greatest. In the opposite case, if there is the minimum point, or the scale of public sector is close to it, nationalization is most probable. It can take the forms of private assets purchase by the state, or expropriation of assets parts, or legal registration of such action (in case that the previous privatization was illegal or it was carried out with legislation infringement).

If we designate the scale of public sector on product and present its parameters as $\mathrm{k}=\mathrm{Y}_{\mathrm{G}} / \mathrm{Y}_{\mathrm{P}}$, in such kind growth $\mathrm{k}$ will not mean nationalization at all, or decrease of $\mathrm{k}$ will not mean privatization, because connection of product and property value is not direct. For example, it is possible to increase product for the account of involving of production spaces standing idle or additional spaces, or for the account of productivity growth, technological re-equipment of production, and use of other reserves. Thus nationalization and privatization cannot be carried out at all and the property structure in the economy will remain unchanged. We will designate the scale of public and private sectors accordingly $\sigma=\mathrm{Y}_{\mathrm{G}} / \mathrm{P}, \tau=\mathrm{Y}_{\mathrm{P}} / \mathrm{P}$, having $\mathrm{y}=\mathrm{Y} / \mathrm{P}=\mathrm{Y}_{\mathrm{G}} / \mathrm{P}+\mathrm{Y}_{\mathrm{P}} / \mathrm{P}=\tau+\sigma$, then $\mathrm{k}=\sigma / \tau=\mathrm{y} /$ $\tau-1=\mathrm{Y} /(\mathrm{P} \tau)-1$. Analyzing function $\mathrm{k}(\mathrm{t})$ on the extremum, we will receive: $\mathrm{dk}$ $(\mathrm{t}) / \mathrm{dt}=0$. Taking a derivative and equating it to zero and carrying out algebraic manipulations, we will receive:

$$
\frac{d \sigma}{d t}=\frac{d y}{d t}+\frac{\tau}{P} \frac{d P}{d t}-\frac{\tau}{Y} \frac{d Y}{d t}
$$


At $\mathrm{dk}(\mathrm{t}) / \mathrm{dt}>0, \mathrm{t}<\mathrm{t} 0, \mathrm{dk}(\mathrm{t}) / \mathrm{dt}<0, \mathrm{t}>\mathrm{t} 0$, we have the maximum point of the scale of public sector at realization of expression $\left.{ }^{* *}\right)$. If $\mathrm{dk}(\mathrm{t}) / \mathrm{dt}<0, \mathrm{t}<\mathrm{t} 0, \mathrm{dk}(\mathrm{t}) /$ $\mathrm{dt}>0, \mathrm{t}>\mathrm{t} 0$ we have the minimum point of the scale of public sector.

Equation $\left(^{* *}\right)$ means, that increase of gross product, to be more precise product change, depends on the change of production, number of employed (with a plus sign, the more this change is, the greater is the product), and on product value in public sector per one employed (with a minus sign: the higher this change is, the greater the inhibition of product growth is). At least it is true for the state of economy when there is the greatest or the least meaning of public sector (according to its product in relation to product in private sector).

Privatization and nationalization can be presented graphically as it is shown in the Figure 1.

Figure 1: Privatization, nationalization and neutral situation
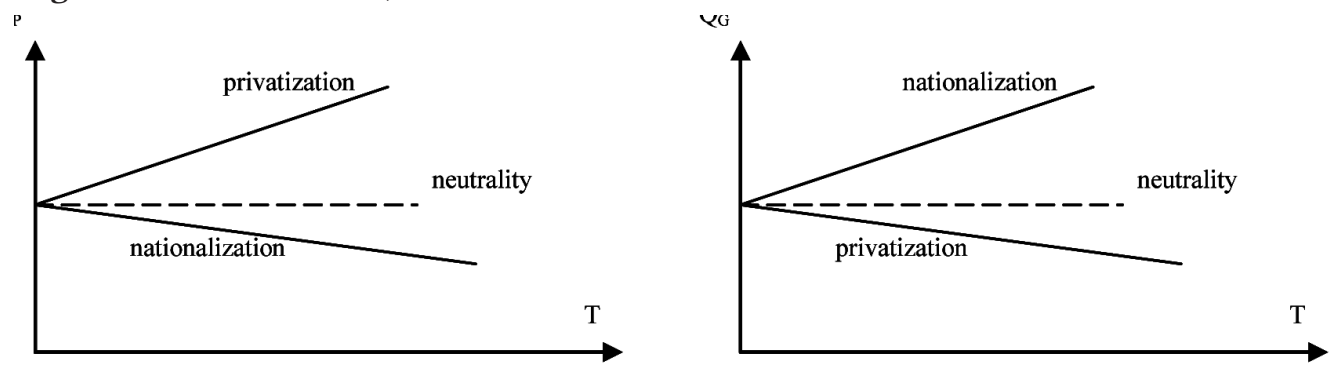

Thus, public property increase at nationalization is usually accompanied by private property reduction and vice versa. At the same time, being the general property value in economy $Q=Q_{P}+Q_{G}$, its gain is connected with privatization or nationalization in no way on some short interval. Certainly, in the future, privatization or nationalization, as it is considered, should lead to more effective economic growth and accelerate its rate, but in foreseeable time period both processes lead only to redistribution of property (assets), whether they are carried out simultaneously or separately. However, economic growth, which accompanies these processes, could occur in neutral situation (absence of privatization and/or nationalization). It provides real income augmentation, which is expressed in property augmentation of two types. This gain is connected with privatization and/or nationalization in no way. Then the increased property value will equal to : $\mathrm{Q}+\Delta \mathrm{Q}=\mathrm{Q}_{\mathrm{P}}+\mathrm{Q}_{\mathrm{G}}+\Delta \mathrm{Q}_{\mathrm{P}}+\Delta \mathrm{Q}_{\mathrm{G}}$, where $\Delta \mathrm{Q}=\Delta \mathrm{Q}_{\mathrm{P}}+$ $\Delta \mathrm{Q}_{\mathrm{G}}$ - augmentation of public and private property accordingly, dependent on current economic growth, but not on privatization/nationalization. If we have reduction of $\Delta \mathrm{Q}$, because of, for example, macroeconomic crisis, the choice concerning privatization and nationalization also depends on the reasons of this crisis, its inertia and depth, but it is not determined purely by nationalization and privatization problems. It is possible, that the most expedient government 
position would be neutrality, as the meaning of privatization and nationalization for "starting" economic growth to oppose crisis is not obvious. That is because the given processes mainly redistribute the property on a short time interval and it is not absolutely clear, what institutions will appear and how the assets will be used on medium and long time intervals under conditions of crisis. Costs can be so high, that they will completely devalue the effectiveness of the specified tools under conditions of economic crisis.

Depending on initial correlation of public and private property two kinds of diagrams reflecting the processes of privatization and nationalization (See Figure 2-3) are possible.

Figure 2: Correlation of property kinds (privatization)
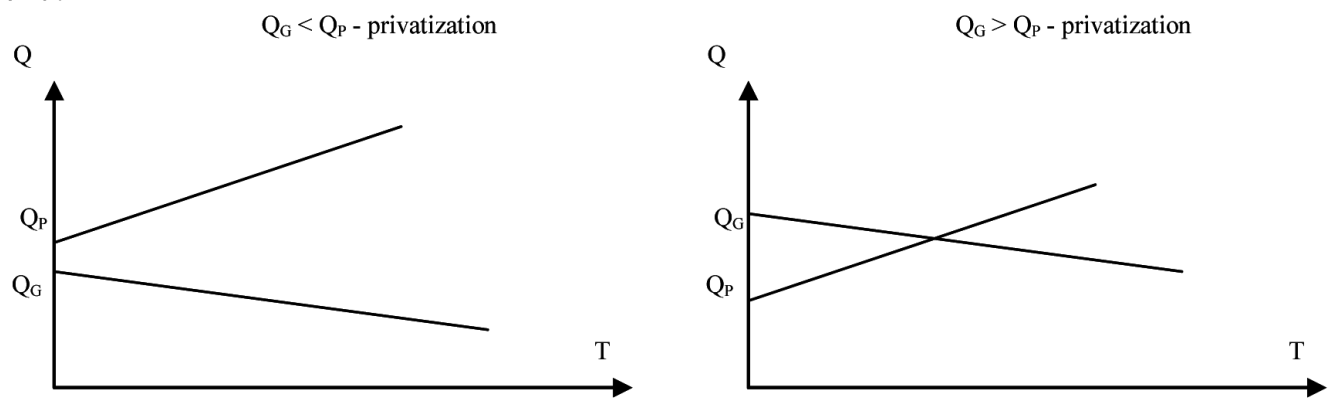

Figure 3: Correlation of property kinds (nationalization) $\mathrm{Q}_{\mathrm{G}}<\mathrm{Q}_{\mathrm{P}}$ - nationalization
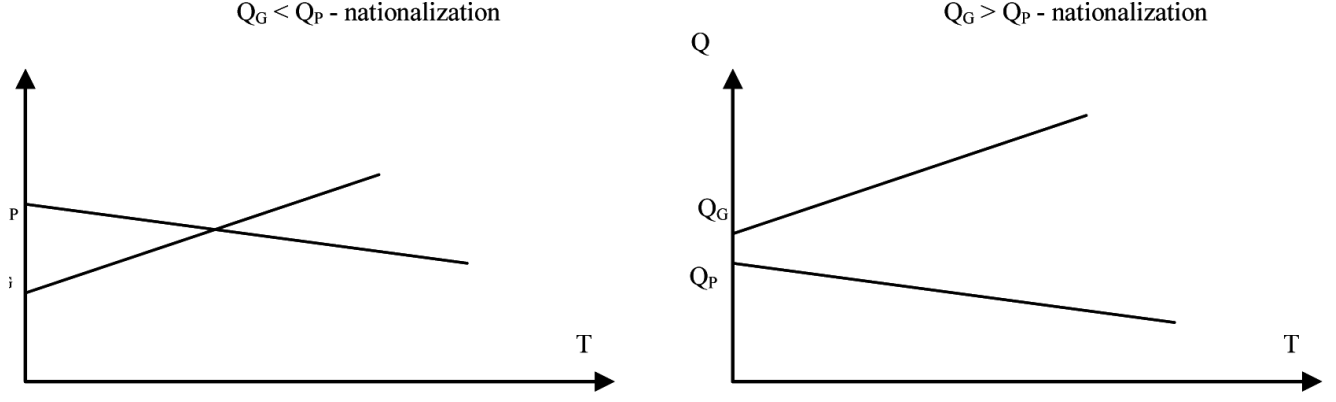

Focusing on the basic identity $\left(D_{P}+Z_{P}+D_{N}+Z_{N}>0\right)$, according to the scale of privatization ( $\alpha$ ) and nationalization $(\beta)$, it is possible to show costs and income change during nationalization and privatization (See Figure 4).

At $\alpha<\alpha^{*}$ we have surplus of privatization income over all the costs (in the discounted form). Therefore, privatization is actual according to this criterion. At higher scale a privatization is inefficient. In other words, in each case it is necessary to create scenarios of change of prospective income and costs to have similar diagrams and to estimate how effective privatization is, at least roughly. As we see, the situation is theoretically quite possible, when having a significant 
scale, privatization is inefficient and cannot be carried out even on financial criterion, to say nothing about all other possible criteria.

Figure 4: Correlation of income and costs at nationalization and privatization depending on the scale of these processes

$\mathrm{D}$

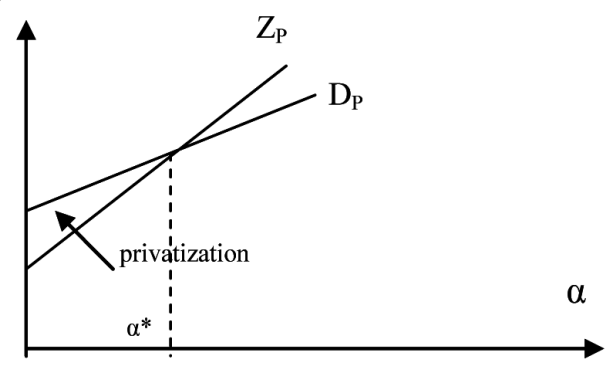

$\mathrm{D}$

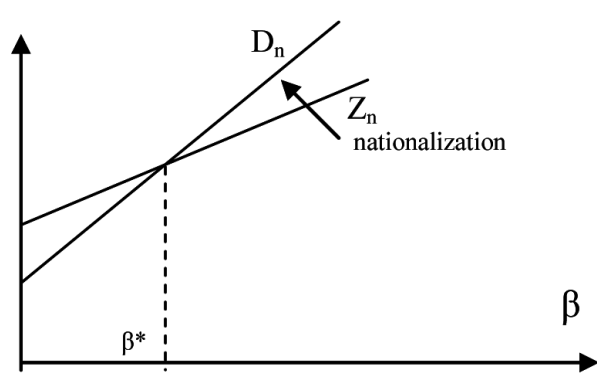

It does not mean that, when $\alpha>a^{*}$, nationalization is necessary. There is no such direct relationship. On the right in the Figure it is shown, that nationalization is expedient according to financial criterion at $\beta>\beta^{*}$, as in this zone incomes from nationalization are higher than costs. In intersection of income and costs curves for corresponding values $\alpha^{*}, \beta^{*}$ accordingly privatization and nationalization are inexpedient, however, generally these points are not connected.

It is interesting to note, that nationalization in the classical statement of question, that is, when the state buys out a certain asset which is in private property, is an original "privatization" only in the private sector when a private owner sells a part of the property, only not to other private owner, but to the state. If the property is resold from private owner to private one, it is not nationalization. These are usual transactions of property sale-purchase. From the position of the state the act of property sale of private owner to the state is nationalization. From the position of private owner who loses this asset, but receives a certain money equivalent for it, it is an original "privatization“ (of course, the original meaning of privatization is reduction of state property due to its sale and acquisition of some income as a result of this action). I have used such incorrect statement on purpose, to show the importance of consideration of income and costs change both for the state, and for private proprietor.

During nationalization the state buys a certain asset which is in private property and brings income $\mathrm{D}_{1}$ for private owner at the moment of nationalization. He buys at price $P_{n}$ which generally should surpass the discounted income $D_{1}$. Otherwise it will be unprofitable for private owner to sell this property. However, if the asset continued to be private property, its income would make $\mathrm{D}_{2}$ minus tax deductions to the state for some time [t1, t2]. If the waiting probability of this income is great and it is higher, than the price of nationalization $\mathrm{P}_{n}$, purely financially it is not profitable for private owner to sell this asset if there are no 
other reasons. For the state $\mathrm{P}_{\mathrm{n}}$ are costs of nationalization, and the income arises when the asset starts working during time [t1, t2] within the limits of its public management. It is income $\mathrm{D}_{3}$, including taxes. But thus the state will lose tax revenues, which would occur if the asset was in the private property. The value of tax revenues for a certain subsequent period of time $[\mathrm{t} 1, \mathrm{t} 2]$ is $(\mathrm{N}(\mathrm{t}))$, where $\mathrm{i}$ - is a discount norm.

In other words, a „locking condition“ for nationalization is:

$$
\begin{aligned}
& P_{n}<\int_{t 1}^{t 2} \frac{D_{2}(t)-N(t)}{(1+i)^{t}} d \\
& P_{n}<D_{1}
\end{aligned}
$$

In this case the private owner should have other very serious reasons to sell the property to the state. Even if price $P_{n}$ is much higher than total discounted expected income for the foreseeable period of time or over the current received income from asset use by the moment of nationalization, it is not at all the fact that the private owner will agree to sell this asset at the given price. If this asset brings positive net profit, there is a question: may be, it would be better to keep it from the point of view of prospect, rather than to sell it to the state. It will be defined by the connection of the asset within the structure of private property of a certain owner. The future positive discounted income could be less than the current price of sale, but it will not be an incentive for a private owner to let the state have this asset at this price. The state should incur large expenses on asset purchase during nationalization to overcome conservative inertia of proprietor's motives. As we can see, this conclusion is very important.During privatization, it is better to lower the price to motivate the proprietor for purchase. Thereby, the effect of information asymmetry during privatization and nationalization demands from the state additional expenses. At nationalization they are direct; at privatization in they are in the form of less received income from property sale.

Hence, conditions of nationalization for the private owner will be inverse:

$$
\begin{aligned}
& P_{n}>\int_{t 1}^{t 2} \frac{D_{2}(t)-N(t)}{(1+i)^{t}} d t \\
& P_{n}>D_{1}
\end{aligned}
$$

Certainly, in each case on each kind of asset there may be different aggregate results. But on the average the specified feature for privatization and nationalization tools remains.

If the state makes decision concerning nationalization, the elementary financial criterion for it should be the condition:

$$
P_{n}<\int_{t 1}^{t 2} \frac{D_{3}(t)-N(t)}{(1+i)^{t}} d t
$$


Certainly, nationalization can be considered as investment to private sector on its property. As well as privatization can be considered as investments of private sector into public sector on its property. The property can be considered as a certain security, or it cannot be transferred in full possession, but in restricted possession, or it can be leased. Here special institutional forms are possible which can be developed and, thereby, vary privatization and nationalization tools, presenting them as investment tools.

If the equality of the right and the left parts of the given „criteria“ inequalities are observed, additional efforts on decision-making concerning nationalization are required.

Combining the conditions of nationalization for the agent and the state, we will receive the criterion:

$$
\int_{t 1}^{t 2} \frac{D_{2}(t)}{(1+i(t))^{t}} d t<\int_{t 1}^{t 2} \frac{D_{3}(t)}{(1+i(t))^{t}} d t
$$

In other words, if the asset which is subject to nationalization in private sector is not nationalized on the period [t $1, t 2]$, aggregate discounted income of it should be less than aggregate discounted income of this asset in state sector after nationalization carried out in the same period [t1, $t 2]$. Thus, we will define the time of carrying out nationalization as small in comparison with time interval $[\mathrm{t} 1, \mathrm{t} 2]$.

The income from the asset use during nationalization should be lowered on the value of expenses $\left(\mathrm{Z}_{\mathrm{T}}\right)$ of nationalization as an operated process. And these expenses are not included into operation period [t1, t2] of already nationalized asset. They should be added to expenses $P_{n}$, or simply be considered in $P_{n}$. If they are not considered, then:

$$
\begin{aligned}
& P_{n}+Z_{n}<\int_{t 1}^{t 2} \frac{D_{3}(t)-N(t)}{(1+i)^{t}} d t \\
& \int_{t 1}^{t 2} \frac{D_{2}(t)}{(1+i(t))^{t}} d t<\int_{t 1}^{t 2} \frac{D_{3}(t)}{(1+i(t))^{t}} d t-Z_{n}
\end{aligned}
$$

At carrying out of nationalization and - or privatization, the aspect concerning how welfare value on segment $[\mathrm{t} 1, \mathrm{t} 2]$ changes. Here, it is necessary to define what to consider welfare and its change. It is obviously possible to define, that net profit change (income minus costs of privatization and nationalization) will characterize the change of welfare of the system. Or it is even better to present it in the form of change of the value added per unit of a kind of property in public and private sectors of economy accordingly. 
The basic identity of privatization-nationalization process actually establishes that net profit (income minus total costs) of privatization and nationalization should be more than zero for the set time interval. Thereby, welfare of the system should increase, and the process of nationalization and/or privatization should not reduce the standard of well-being. After all, the part of assets can be lost during property sale at privatization and at property purchase during nationalization. Nationalization can have the forms are not absolutely connected with property purchase. These losses are equivalent to the situation when the crop from the fields is carried to the place of destination. There is always transport and other losses connected with damage of agricultural production. Though for the property which is not foodstuffs, "the effect of damage“ is not inherent. Nevertheless, losses can be connected with substitution effect of assets, change of assets structure and changing of their specialty, and with the second stage of privatization, when a new proprietor can break up the asset (property), rearrange it and this time sell to the private person. The same is characteristic for nationalization. However, the state behaves in a similar way, playing the role of proprietor and buyer of the given asset. If, for example, both privatization and nationalization are carried out in the economic system (such variant is not usually considered by economists), all the same, some process will be prevailing, for example, on the value of cost of the asset sold (privatization) or the asset bought (nationalization). Then it is necessary to say, that nationalization is carried in the economy. Though, from the point of view of pure theory it will not be absolutely correct, because the given kind of process will be simply prevailing and nothing more.

Well-being of economic system can be presented as the value of property which the agents of this system possess. Then for the given level of the income (product) $\mathrm{U}(\mathrm{Y})=\mathrm{Q}_{\mathrm{G}}(\mathrm{Y})+\mathrm{Q}_{\mathrm{P}}(\mathrm{Y})$. Generally, having the functions of change of property value from the product, it is possible to write down

$$
U=\int_{Y 0}^{Y^{*}}\left(Q_{G}(Y)+Q_{P}(Y)\right) d Y
$$

If we present, for example, privatization and nationalization by the change of public and a private property value accordingly depending on gross domestic product $\mathrm{Y}$, believing, that privatization and nationalization processes are connected with growth $\mathrm{Y}$, then the situation can be represented in a simplified form for constant speed of privatization and nationalization as it is shown in Figure 5 . 
Figure 5: Privatization and Nationalization at Growth and Decline of Gross Domestic Product
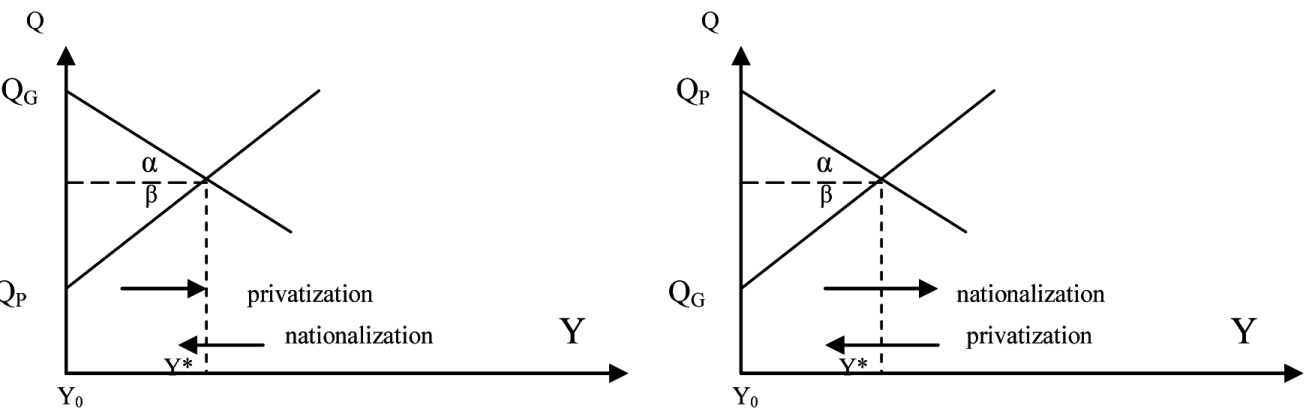

As we see, the situation is set by the initial prevalence of public sector in one case and prevalence of private sector in the other case. Diagrams reflect the possibilities of privatization and nationalization at growth of Y. At inverse movement of $\mathrm{Y}$, that is, at decline, the diagram reflects nationalization (on the left) and privatization (on the right).

On the assumption of graphic layout for random product $Y$, we will write down: $\mathrm{Q}_{\mathrm{G}}=\mathrm{Q}_{\mathrm{P}}+\mathrm{k}\left(\mathrm{Y}^{*}-\mathrm{Y}\right)$, where $\mathrm{k}=(\operatorname{tg} \alpha+\operatorname{tg} \beta)$. Well-being for given product $\mathrm{Y}$ at nationalization (Figure, on the right) as $\mathrm{Q}_{\mathrm{P}}=\mathrm{Q}_{\mathrm{G}}+\mathrm{k}\left(\mathrm{Y}^{*} \mathrm{Y}\right)$, will be: $\mathrm{U}(\mathrm{Y})=2$ $\mathrm{Q}_{\mathrm{G}}+\left(\mathrm{Y}^{*}-\mathrm{Y}\right) \mathrm{k}$.

Well-being change on time and product accordingly will be: $\mathrm{dU} / \mathrm{dt}=2 \mathrm{dQ} \mathrm{G}_{\mathrm{G}}$ I $\mathrm{dt}-\mathrm{k}\{\mathrm{dY} / \mathrm{dt}\} ; \mathrm{dU} / \mathrm{dY}=2 \mathrm{dQ}_{\mathrm{G}} / \mathrm{dY}-\mathrm{k}$. Or $\mathrm{U}(\mathrm{Y})=2 \mathrm{Q}_{\mathrm{P}}+\left(\mathrm{Y}-\mathrm{Y}^{\star}\right) \mathrm{k}$. Then $\mathrm{dU} / \mathrm{dt}=2$ $\mathrm{dQ}_{\mathrm{p}} / \mathrm{dt}+\mathrm{k}\{\mathrm{dY} / \mathrm{dt}\} ; \mathrm{dU} / \mathrm{dY}=2 \mathrm{dQ}_{\mathrm{p}} / \mathrm{dY}+\mathrm{k}$. The result of change of system wellbeing depends on the angle of inclination symbolizing privatization and nationalization speed accordingly, initial correlation of private and public property, and the rate of current economic growth. If sensibility in the form of angles of inclination is time function, but the equilibrium volume $\mathrm{Y}^{\star}$ for the given interval does not change, then the change of wellbeing of the system at nationalization (Figure 5, on the right) corresponds to the introduced criterion:

$$
\begin{aligned}
& \frac{d U}{d t}=2 \frac{d Q_{P}}{d t}+\left(Y-Y^{*}\right) \frac{d k}{d t}+k \frac{d Y}{d t} \text { Or } \\
& \frac{d U}{d t}=2 \frac{d Q_{G}}{d t}-\left(Y-Y^{*}\right) \frac{d k}{d t}-k \frac{d Y}{d t}
\end{aligned}
$$

Thus, the change of system well-being is defined by the rate of change of private property, sensibility of change of property structure at economy growth and the rate of economic growth itself with proportionality coefficients at each component.

Well-being change at privatization (Figure 5, on the left), will be:

$$
\frac{d U}{d t}=2 \frac{d Q_{G}}{d t}+\left(Y-Y^{*}\right) \frac{d k}{d t}+k \frac{d Y}{d t}
$$


Certainly, formulating the diagram in such a way other sets of factors which can be rather significant at privatization and nationalization are rejected.

\section{Literature}

- Sukharev O. S. (2013): Privatization, Nationalization and Economic Reform, Finance and statistics, Moscow

- Sukharev O.S. (2013): Theory of economic changes: problems and decisions, KRASAND, Moscow

- Sappington D., Stiglitz J. (1987): „Privatization, Information and Incentives,", Journal of Political Analysis and Management, Vol. 6, № 4, 567582.

- Sukharev O.S. (2009): Efficiency Theory in Economy (2009), Finances and Statistics, Moscow. 


\section{INSTITUCIONALNA EKONOMSKA TEORIJA SREDSTAVA PRIVATIZACIJE I NACIONALIZACIJE: OSNOVNI IMPERATIVI}

\section{S a ž e $t$ a $k$}

Predstavljene su osnovne odredbe principa i kriterijuma institucionalne teorije privatizacije - nacionalizacije, kao i upravljanje imovinom u ekonomiji. Sprovedena je strukturna analiza imovine, u pogledu njena dva osnovna elementa, javne i privatne imovine, kao i predstavljanje modela interakcije u javnom i privatnom sektoru. Glavna pažnja je usmerena na efikasnost prilikom procene kriterijuma funkcionisanja imovine kao i na odgovarajuću validaciju imovine u privatizaciji i nacionalizaciji. Predložen je optimalni princip strukture imovine u ekonomskom sistemu. Izvršena je analiza karakteristika privatizacije i nacionalizacije u ekonomskom pogledu, polazeći od validacije teorijskih kriterijuma privatizacije i nacionalizacije u ekonomiji.

Ključne reči: imovina, struktura, privatizacija, nacionalizacija, efikasnost kriterijuma, optimalni principi 